\title{
Çocuklarda Mikafungin Kullanımının Değerlendirilmesi
}

\section{Evaluation of Micafungin Use in Children}

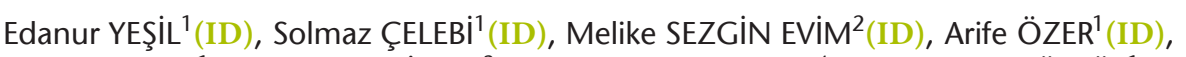

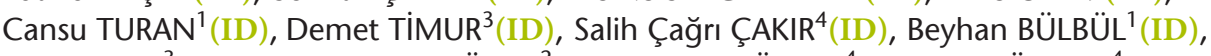 \\ Beyza ENER ${ }^{3}(\mathrm{ID})^{1}$, Adalet Meral GÜNES ${ }^{2}$

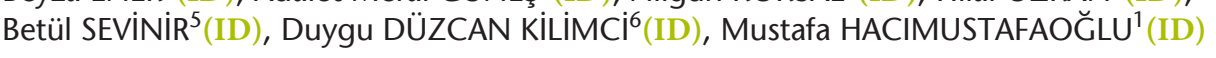 \\ ${ }^{1}$ Uludağ Üniversitesi Tıp Fakültesi, Çocuk Enfeksiyon Hastalıkları Bilim Dalı, Bursa. \\ ${ }^{1}$ Uludag University Faculty of Medicine, Department of Pediatric Infectious Diseases, Bursa, Turkey. \\ 2 Uludağ Üniversitesi Tıp Fakültesi, Çocuk Hematoloji Bilim Dalı, Bursa. \\ 2 Uludag University Faculty of Medicine, Department of Pediatric Hematology, Bursa, Turkey. \\ ${ }^{3}$ Uludağ Üniversitesi Tıp Fakültesi, Tıbbi Mikoloji Bilim Dalı, Bursa. \\ ${ }^{3}$ Uludag University Faculty of Medicine, Department of Medical Mycology, Bursa, Turkey. \\ ${ }^{4}$ Uludağ Üniversitesi Tıp Fakültesi, Neonatoloji Bilim Dalı, Bursa. \\ ${ }^{4}$ Uludag University Faculty of Medicine, Department of Neonatology, Bursa, Turkey. \\ ${ }_{5}^{5}$ Uludağ Üniversitesi Tıp Fakültesi, Çocuk Onkoloji Bilim Dalı, Bursa. \\ ${ }^{5}$ Uludag University Faculty of Medicine, Department of Pediatric Oncology, Bursa, Turkey. \\ ${ }^{6}$ Celal Bayar Üniversitesi Tıp Fakültesi, Çocuk Endokrinoloji Bilim Dalı, Manisa. \\ ${ }^{6}$ Celal Bayar University Faculty of Medicine, Department of Pediatric Endocrinology, Manisa, Turkey.
}

* Bu çalışma, 34. Antibiyotik ve Kemoterapi Derneği (ANKEM) Kongresi (1-5 Mayıs 2019, Marmaris)'nde sözlü bildiri birincilik ödülü almıştır.

Makale Atıfı: Yeşil E, Çelebi S, Sezgin Evim M, Özer A, Turan C, Timur D ve ark. Çocuklarda mikafungin kullanımının değerlendirilmesi. Mikrobiyol Bul 2020;54(1):120-134.

\section{ÖZ}

Mikafungin, invaziv kandidiyazis gibi bilinen öncelikli endikasyonları dışında, beklenen yan etki potansiyelinin düşük olması nedeniyle, özellikle karaciğer ve böbrek yetmezliği bulguları gelişmiş olan ve diğer grup antifungallere bağlı yan etki gözlenmiş hastalarda önerilmektedir. Bu çalışmada mikafungin tedavisi alan çocuk olguların değerlendirilmesi amaçlanmıştır. Hastanemiz çocuk klinik ve yoğun bakım ünitelerinde Kasım 2016-Ocak 2019 tarihleri arasında yatan ve mikafungin kullanılan 125 çocuk olgu retrospektif olarak incelenmiştir. Klinik veriler, mikafungin endikasyonu, tedavinin birinci ve dördüncü günü kan değerleri, ilaç yan etkileri ve etkinliği değerlendirilmiştir. Olguların \%60 (75/125)'ı erkek olup, ortalama yaş $58 \pm 67$ (0215.30) ay olarak belirlenmiştir. Olguların yaklaşık yarısında (\%48) malignansi, \%13'ünde ise prematürite komorbiditeleri saptanmıştır. Malignansili olguların \%62 $(n=37)$ 'sini hematolojik [akut lenfositik lösemi $(n=$ 27), akut miyeloid lösemi $(n=9)$, miyelodisplastik sendrom $(n=1)], \% 38(n=23)^{\prime}$ ini ise onkolojik [nöroblastom $(n=6)$, Hodgkin lenfoma $(n=4)$, non-Hodgkin lenfoma $(n=2)$, sarkom $(n=5)$, hepatoblastom $(n=$ 1), diğerleri $(n=5)$ ] malignansilerin oluşturduğu tespit edilmiştir. Majör yatış nedenini sepsis (\%53) oluşturmuştur. Olguların immünsupresan tedavi $(n=68, \% 54)$, nötropeni $(n=61, \% 49)$, santral venöz kateter $(n=$ $102, \% 82)$, nazogastrik sonda $(n=63, \% 50)$, endotrakeal entübasyon tüpü $(n=49, \% 39)$, idrar sondası $(n=$ $14, \% 11)$, total parenteral beslenme $(n=81, \% 65)$ gibi çeşitli risk faktörleri olduğu gözlenmiştir. Olguların 16059, Görükle, Bursa, Türkiye. Tel (Phone): +90 224295 0538, E-posta (E-mail): eda_hacettepe@hotmail.com 
\%13 ( $n=16)^{\prime}$ 'ünü postoperatif hastalar oluşturmuştur. Toplam 23 (\%18) hastanın 97 adet klinik örneğinde (kan, endotrakeal aspirat sıvısı, balgam, idrar vb.) Candida türleri üremiştir. Candida türleri üreyen hastaların 13 'ünde üreme kan kültürlerinde olup izolatların çoğunluğunu $(n=8, \% 62)$ Candida albicans dışı türler oluşturmuştur. Kandidemilerin tamamında izolatlar ekinokandin duyarlı olup, medyan dört gün içerisinde kan kültürleri negatifleşmiştir. Tüm olgular $(n=125)$ değerlendirildiğinde mikafunginin dördüncü gününde C-reaktif protein düzeyinde anlamlı azalma, sodyumda hipernatremi olmaksızın artış, alanin aminotransferaz yüksekliğinde gerileme olduğu görülmüştür $(p<0.05)$. Toplam 39 (\%31) hastada mikafungin tedavisi öncesinde medyan yedi (1-60) gün çeşitli antifungal tedaviler kullanılmışır. Bu 39 hastanın 14 (\%36)'ünde karaciğer fonksiyon testleri (KCFT)'nde bozukluk, 10 (\%26)'unda hipokalemi, 5 (\%13)'inde böbrek fonksiyon testlerinde bozukluk olduğu görülmüştür. On (\%26) hastada önceki antifungale bağlı gelişen hipokalemi; mikafungin tedavisi sonrası düzelmiştir $(\mathrm{p}=0.0001)$. Antifungale bağıı olsun/olmasın KCFT'de bozukluk nedeniyle mikafungin verilen hastalarda $(n=47, \% 38)$ izlemde alanin aminotransferaz ve aspartat aminotransferazda gerileme görülmüştür (sırasıyla, $p=0.0001$ ve $p=0.0001$ ). Mikafungin tedavisinin ilk 30 günü içerisinde 19 (\%15) hasta kaybedilmiş olup, birinde kandidemi tespit edilmiştir. Hiçbir hastada mikafungin ilişkili önemli bir yan etki gözlenmemiştir. Çalışmamız mikafunginin, karaciğer ve böbrek fonksiyon testlerinin yüksek olduğu yenidoğan dahil çocuk olgularda, güvenli ve etkili bir seçenek olabileceğini göstermiştir.

Anahtar kelimeler: Antifungal; çocukluk dönemi; mikafungin.

\section{ABSTRACT}

Micafungin is recommended especially in patients with liver and kidney failure and in the presence of other side effects due to antifungals apart from its known priority indications such as invasive candidiasis. The aim of this study was to evaluate the children who have received micafungin treatment. In the study, 125 children who were hospitalized in the pediatric wards and intensive care units of our hospital and had used micafungin between November 2016 and January 2019 were analyzed retrospectively. Clinical data, micafungin indication, blood values on the first and fourth days of the treatment, side effects of the drug and efficacy were evaluated. Sixty percent $(75 / 125)$ of the patients were male and the mean age of all the patients were $58 \pm 67(0-215,30)$ months. Approximately half of the cases $(48 \%)$ had malignancy and $13 \%$ of them were premature. Sixty-two percent $(n=37)$ of the malignencies were hematological $(27$ acute lymphocytic leukemia, nine acute myeloid leukemia, one myelodysplastic syndrome) and $38 \%$ ( $n=$ 23) were oncological (six neuroblastoma, four Hodgkin lymphoma, two Non-Hodgkin's lymphoma, five sarcomas, one hepatoblastoma, five others) malignencies. The major cause of hospitalization was sepsis (53\%). The patients had several risk factors like immunosuppressive therapy $(n=68,54 \%)$, neutropenia $(n=$ $61,49 \%)$, central venous catheter $(n=102,82 \%)$, nasogastric tube $(n=63,50 \%)$, endotracheal intubation tube $(n=49,39 \%)$, urinary catheter $(n=14,11 \%)$ and total parenteral nutrition $(n=81,65 \%)$. Thirteen percent $(n=16)$ of the cases were post-operative patients. Candida species were cultivated in 97 clinical specimens (blood, endotracheal aspirate, sputum, urine, etc.) among 23 (18\%) of the patients. Thirteen $(10 \%)$ of the patients had candidemia and $62 \%$ of them were non-albicans strains. In all candidemias, strains were echinocandin susceptible, and blood cultures were negative within four days. When all the patients $(n=125)$ were evaluated, a significant decrease in C-reactive protein, an increase in sodium, and a decrease in alanine aminotransferase were observed on the fourth day of micafungin treatment $(p<0.05)$. A total of 39 (31\%) patients underwent various antifungal treatments for median seven (1-60) days prior to micafungin treatment. Fourteen (36\%) of these 39 patients, had elevated liver function tests (LFT), 10 (26\%) of them had hypokalemia, and five (13\%) of them had elevated renal function tests. Ten (26\%) patients had antifungal-induced hypokalemia previously; and potassium levels were normalized after micafungin treatment $(p=0.0001)$. The patients for which micafungin treatment was chosen due to elevated liver function tests $(n=47,38 \%)$, whether the antifungal induced or not; alanine aminotransferase and aspartate aminotransferase levels were decreased after micafungin treatment $(p=0.0001$ and $p=0.0001$, respectively). Nineteen (15\%) of the patients have died within the first 30 days of micafungin treatment and one of them had candidemia. No micafungin treatment related significant side effects were observed in any of the patients. Our study showed that micafungin could be a safe and effective option in pediatric cases including newborns with high liver and kidney function tests.

Keywords: Antifungal; childhood; micafungin. 


\section{Gíriş}

Ekinokandinler insan hücrelerinde bulunmayan 1,3- $\beta$-D-glukan sentezini inhibe ederek etki gösteren kaspofungin, mikafungin ve anidulafunginden oluşan bir antifungal grubudur $^{1}$. Anidulafungin, erişkin popülasyonda randomize kontrollü çalışmalarla güvenlik ve etkinliğini kanıtlayabilmişken, pediatrik popülasyonda bu konuda yetersiz sayıda farmakokinetik çalışma olması nedeniyle kullanım onayı alamamıştır ${ }^{2}$. Amerikan Gıda ve İlaç İdaresi (Food and Drug Administration, FDA), üç ay ve üzeri çocuklarda kaspofungin kullanımını, dört ay ve üzeri çocuklarda ise mikafungin kullanımını onaylamıştır ${ }^{3}$. Mikafungin yenidoğan dahil tüm yaş gruplarında Avrupa ilaç Ajansı (European Medicines Agency, EMA) tarafından onaylıdır ${ }^{4}$. Mikafungin ve kaspofungin yarı sentetik lipopeptitler olup pediatrik hastalarda invaziv kandidiyazis tedavisinde, intravenöz tedavinin uygun olduğu özefageal kandidiyazis tedavisinde, invaziv aspergillozun kurtarma tedavisinde, febril nötropeninin ampirik tedavisinde endikedir ${ }^{2,5}$. Kaspofungin geçici transaminaz yüksekliği yapmakla birlikte hafif karaciğer ile böbrek yetersizliklerinde doz ayarlaması gerektirmemektedir. Mikafungin kullanımında da böbrek ve hafif-orta karaciğer yetersizliklerinde doz ayarlaması yapılmaz. Genel olarak ekinokandinlerin göz, idrar ve beyin omurilik sıvısı (BOS) dışında diğer enfeksiyon bölgelerinde yeterli terapötik düzeye ulaşabildiği bilinirken, mikafunginin yenidoğanda $10 \mathrm{mg} / \mathrm{kg} /$ gün dozunda BOS'a geçtiği gösterilmiştir 2,4,5. Mikafungin Candida türlerine karşı fungisidal, Aspergillus türlerine karşı fungistatik etkilidir.

Memelilerde hücre duvarı bulunmaması nedeniyle, mantar hücre duvarına etkili olan mikafunginin toksik etkisinin minimal olması beklenir ve bu nedenle yüksek dozlarda tolere edilebilir. Bununla birlikte, bulantı, kusma, ishal gibi gastrointestinal yan etkilere, yüksek ateş, infüzyonla ilişkili reaksiyonlara, filebit, karaciğer enzimlerinde yükselme, alkalen fosfataz yüksekliği, hipoglisemi, elektrolit bozukluğu gibi yan etkilere neden olabildiği saptanmıştır ${ }^{6}$. Mikafungin kliniğimizde, öncelikli olarak invaziv kandidiyazis olgularında kullanılmakla birlikte, yan etki potansiyelinin düşük olması nedeniyle, özellikle karaciğer ve böbrek yetmezliği bulguları gelişmiş olan hastalar ile diğer grup antifungallere bağlı yan etki gözlenmiş hastalarda da kullanılmaktadır. Mikafunginin yenidoğan ve çocukluk yaş grubunda kullanım deneyimi ve bu konuda yapılan çalışmalar sınırlıdır. Bu çalışmada, antifungal tedavide mikafungin kullanılan olguların klinik verilerini araştırmak, etki ve yan etki durumunu incelemek, laboratuvar parametrelerini tedavi öncesi ve sonrası karşılaştırarak Türkiye'de pediatrik hastalarda yakın zamanda kullanıma giren mikafungin tedavisi ile ilgili deneyimlerimizi paylaşmak ve verilerimizi mevcut literatür eşliğinde tartışmak amaçlanmıştır.

\section{GEREÇ ve YÖNTEM}

Bu çalışma, Uludağ Üniversitesi Tıp Fakültesi Klinik Araştırmalar Etik Kurulu onayı ile gerçekleştirildi (Tarih: 26.02.2019, Karar no: 2019-4/22).

Çalışmamızda, çocuk sağlığı ve hastalıkları kliniklerinde (yenidoğan ve çocuk yoğun bakım üniteleri, hematoloji-onkoloji hastanesi, diğer yan dal klinikleri) Kasım 2016-Ocak 
2019 tarihleri arasında yatan ve antifungal tedavi olarak mikafungin endikasyonu konulan hastalar retrospektif olarak incelendi. Hastalar yatış tanısı, komorbiditeleri, kültürleri, fungal enfeksiyon gelişimi açısından risk faktörleri, mikafungin başlama endikasyonu, tedavi öncesi-sonrası kan biyokimyası karşılaştırılması, olası ilaç yan etkileri ve etkinliğini ölçmek üzere değerlendirildi. Hastaların mikafungin tedavisinin birinci (mikafungin -2 gün/+1 gün arası) ve dördüncü günlerinde (3-5. günler arası) çalışılmış olan lökosit, hemoglobin, trombosit, C-reaktif protein (CRP), üre, kreatinin, alanin aminotransferaz (ALT), aspartat aminotransferaz (AST), sodyum ve potasyum değerleri kaydedildi. Tüm bu verilere retrospektif olarak hastaların elektronik dosyalarından ulaşıldı.

\section{İzolatların Elde Edilmesi ve Tanımlanması}

Kültürler, mikrobiyoloji ve mikoloji laboratuvarında uluslararası standartlara göre çaIışıldı ${ }^{7}$. Laboratuvarımız rutininde, alınmış olan kan ve steril vücut sıvıları BACTEC Peds Plus/Fx (Becton-Dickinson, Sparks, MD, ABD) kültür şişelerine inoküle edildi. Şişeler otomatik kan kültür sisteminde (Becton-Dickinson Diagnostic Instrument Systems, ABD) izlendi. Pozitif sinyal veren şişelerden yapılan Gram boyama işleminde maya görülmesi durumunda kanlı agar ve antibiyotikli Sabouraud dekstroz agara (Becton Dickinson Diagnostic Instrument Systems, ABD) pasajlar yapıldı. Üreyen maya kolonileri germ tüp testi, klamidospor oluşumu, kromojenik besiyerindeki morfoloji ve API ID 32 C sistemi (BioMerieux Diagnostic System, Grenoble, Fransa) kullanılarak tanımlandı. Idrar, derin trakeal aspirat (DTA), balgam, dışkı gibi diğer örnekler SDA, antibiyotikli SDA, Candida için kromojenik besiyeri ve beyin kalp infüzyon agara ekilerek yedi gün takip edildi ve üremeler kan örneklerinde olduğu gibi tanımlandı. Kan, steril vücut sıvıları ve idrar örneklerinde üreyen Candida türlerinin amfoterisin B, flukonazol, itrakonazol, vorikonazol, posakonazol ve anidulafungin in vitro duyarlılıkları "Clinical and Laboratory Standards Institute (CLSI)" M27A-3 yöntemi ile gerçekleştirildi ${ }^{8}$. Elde edilen minimum inhibitör konsantrasyonları (MiK) referans yöntemin ek dokümanına (M27-S3) göre değerlendirildi ${ }^{9}$. Klinik sınır değerlerin olduğu durumlarda sonuçlar duyarlı (S), doza bağlı duyarlı (SDD), orta duyarlı (I) ve dirençli (R) olarak yorumlandı. Klinik sınır değerlerin olmadığı durumlarda epidemiyolojik eşik değerlerden yararlanıldı ${ }^{10}$. Epidemiyolojik eşik değer ve altında olanlar vahşi tip suş, epidemiyolojik eşik değerin üstünde olanlar vahşi olmayan suş olarak tanımlandı.

\section{Tanımlamalar}

Mutlak nötrofil sayısının 1-12 ay arasında $<1000 / \mathrm{mm}^{3}$, diğer yaş gruplarında $<1500 /$ $\mathrm{mm}^{3}$ olması nötropeni olarak tanımlandı. CRP $>0.5 \mathrm{mg} / \mathrm{dl}$ değerleri pozitif olarak kaydedildi ${ }^{11}$. Üçüncü kuşak sefalosporin, karbapenem, aminoglikozid ve glikopeptit kullanımı geniş spektrumlu antibiyotik kullanımı olarak kabul edildi.

Çalışmamızda, invaziv mantar enfeksiyonu (IME) kaynaklar eşliğinde kanıtlanmış (proven), muhtemel (probable) ve olası (possible) olarak üç kategoride literatür eşliğinde tanımlandı ${ }^{12}$. 
Pediatrik enfeksiyon hastalıkları rutinimizde, kılavuzlar doğrultusunda, nötropenik kanser hastalarına, geniş spektrumlu antibiyotik tedavisine rağmen dört günü geçen ya da dört gün sonra yeni çıkan ateş durumlarında, iME düşünülerek ampirik amfoterisin B, ekinokandin ya da vorikonazol kullanılmaktadır ${ }^{13}$. Nötropenik olmayan hastalarda invaziv kandidiyazis tedavisinde flukonazol ya da ekinokandin, nötropenik olgularda ekinokandin ya da lipozomal amfoterisin B tercih edilmektedir ${ }^{14}$. Doğum ağırlığı 1000 gramın altında olan yenidoğanlarda iME profilaksisinde flukonazol kullanılmaktadır. IME gelişen yenidoğanda flukonazol tercih edilirken, flukonazol profilaksisi alanlarda amfoterisin B deoksikolat ya da mikafungin kullanılmaktadır². Tüm yaş grubu hastalarda karaciğer ve böbrek fonksiyon testlerinde bozukluk olan ya da antifungal tedavi yan etki veya toksisitesi gelişen hastalarda ise mikafungin uygun endikasyonu varsa tercih edilmektedir.

\section{İstatistiksel Analiz}

İstatistiksel analizlerde SPSS 23.0 kullanıldı. Tanımlayıcı istatistikler ortalama, standart deviasyon, medyan, minimum ve maksimum olarak verildi. Verilerin karşılaştırılmasında, bağımlı gruplarda normal dağılım gösteren değişkenlerde "Paired Samples T Test", normal dağılım göstermeyen değişkenlerde "non-parametrik Wilcoxon testi" kullanıldı. Normal dağılımlı bir seride üç ve daha fazla bağımsız ortalama arasındaki farkı karşılaştırmak amaçlı normal dağılımlı seride tek yönlü varyans analizi (ANOVA), normal dağılmayan seride Kruskal Wallis analizi kullanıldı. İstatistiksel karşılaştırmalarda anlamlılık düzeyi $\mathrm{p}<0.05$ olarak belirlendi.

\section{BULGULAR}

Kasım 2016-Ocak 2019 tarihleri arasında toplam 125 hastaya ortalama $16 \pm 11.3$ (395, ortanca 15) gün mikafungin tedavisi verilmiştir. Olguların bazı klinik ve demografik özellikleri Tablo I'de, bazı risk faktörleri Tablo II'de özetlenmiştir.

Toplam 23 (\%18) hastanın 97 adet klinik örneğinde (kan, endotrakeal aspirat sıvısı, balgam, idrar vb.) Candida türlerinin ürediği saptanmıştır. Candida türleri üreyen hastaların 13'ünde üreme kan kültürlerinde olup izolatların çoğunluğunu ( $n=8, \% 62)$ Candida albicans dışı türlerin oluşturduğu tespit edilmiştir. Hastaların $6(\% 5)^{\prime}$ sında kandidüri saptanmıştır. Bir hastada kan kültüründe Candida lusitaniae üremesinin yanı sıra idrarında da aynı etkenin ürediği gözlenmiştir. Kalan dört hastada ise değişik bölgelerden (trakeostomi sürüntüsü, dışkı, balgam, kateter) alınan örneklerinde Candida üremesi olduğu saptanmıştır. Ayrıca, bir olguda kan kültüründe Saccharomyces cerevisiae üremiştir.

Kan ve idrar kültürlerinde üreyen toplam 19 izolata antifungal duyarlılık çalışılmıştır. Tablo III'te antifungal duyarlılık sonuçları özetlenmiştir. Kan kültürlerinde Candida ve türleri üreyen olguların tamamında mikafungin tedavisinden medyan dört gün (ortalama $5.9 \pm 3.3$; 2-10 gün aralığında) sonra alınan kan kültürlerinde üreme olmadığı gözlenmiştir.

Tüm hastalarda ( $n=125)$ tedavinin birinci ve dördüncü günü bakılan bazı kan sayımı ve biyokimya değerleri Tablo IV'te sunulmuştur. Mikafungin sonrası istatistiksel olarak 


\begin{tabular}{|c|c|c|}
\hline & Ort \pm SD (min-maks, med) & n (\%) \\
\hline Toplam hasta sayısı & & $125(\% 100)$ \\
\hline Yaş (ay) & $58 \pm 67(0-215,30)$ & \\
\hline Cinsiyet (erkek) & & $75(\% 60)$ \\
\hline \multicolumn{3}{|l|}{ Hastanede yattığı bölüm } \\
\hline ÇHOK & & $61(\% 49)$ \\
\hline YYBÜ & & $33(\% 26)$ \\
\hline ÇSHK ve YBÜ & & $31(\% 25)$ \\
\hline \multicolumn{3}{|l|}{ Yatış tanısı } \\
\hline Sepsis & & $66(\% 53)$ \\
\hline Kemoterapi ve KiT planı & & $30(\% 24)$ \\
\hline Pnömoni & & $10(\% 8)$ \\
\hline Kalp yetmezliği & & $9(\% 7)$ \\
\hline Diğer & & $10(\% 8)$ \\
\hline Hastane yatış süresi (gün) & $57 \pm 43(5-283,48)$ & \\
\hline \multicolumn{3}{|l|}{ Majör komorbidite ${ }^{a}$} \\
\hline Malignansi (hematolojik= 37, onkolojik= 23) & & $60(\% 48)$ \\
\hline Prematürite & & $16(\% 13)$ \\
\hline Postoperatif hasta ${ }^{b}$ & & $16(\% 13)$ \\
\hline Primer immün yetmezlik & & $13(\% 10)$ \\
\hline Serebral palsi & & $9(\% 7)$ \\
\hline Konjenital kalp hastalığı & & $6(\% 5)$ \\
\hline Diğer & & $5(\% 4)$ \\
\hline \multicolumn{3}{|l|}{ İnvaziv mantar enfeksiyonu } \\
\hline Kanıtlı & & $14(\% 11)$ \\
\hline Muhtemel & & $11(\% 9)$ \\
\hline Olası & & $100(\% 80)$ \\
\hline $\begin{array}{l}\text { Mikafunginle eş zamanlı geniş spektrumlu } \\
\text { antibiyotik kullanım süresi, oranı }\end{array}$ & $12 \pm 9.3(0-43,12)$ & $118(\% 94)$ \\
\hline $\begin{array}{l}\text { Mikafungin öncesi çeşitli antifungal tedavilerin } \\
\text { kullanım süresi, sayı ve oranı }{ }^{\mathrm{c}}\end{array}$ & $11 \pm 11.4(1-60.7)$ & $39(\% 31)$ \\
\hline Bu olgularda mikafungine geçiş nedenleri: & & $\mathrm{n} / \mathrm{N}(\%)$ \\
\hline KCFT yüksekliği & & $14 / 39(\% 35)$ \\
\hline Hipokalemi & & $10 / 39(\% 26)$ \\
\hline BFT anormalliği & & $5 / 39(\% 13)$ \\
\hline Yan etki dışı nedenler (klinisyen önerisi) & & $10 / 39(\% 26)$ \\
\hline
\end{tabular}




\begin{tabular}{|c|c|c|}
\hline & Ort \pm SD (min-maks, med) & n (\%) \\
\hline \multicolumn{3}{|c|}{$\begin{array}{l}\text { Mikafungin tedavisi öncesinde olguların bazı } \\
\text { biyokimyasal değerlerinin profili: }\end{array}$} \\
\hline KCFT yüksekliği & & $47(\% 38)$ \\
\hline Hipokalemi & & $21(\% 17)$ \\
\hline BFT anormalliği & & $12(\% 10)$ \\
\hline $\mathrm{KCFT}, \mathrm{BFT}$, potasyum normal & & $45(\% 35)$ \\
\hline Toplam mortalite & & $30(\% 24)$ \\
\hline İlk 30 gün mortalited & & $19(\% 15)$ \\
\hline
\end{tabular}

Ort: Ortalama, SD: Standart sapma, min: Minimum, maks: Maksimum, med: Ortanca, ÇHOK: Çocuk hematoloji ve onkoloji kliniği, YYBÜ: Yenidoğan yoğun bakım ünitesi, ÇSHK: Çocuk sağlığı ve hastalıkları klinikleri, YBÜ:

Yoğun bakım ünitesi, KiT: Kemik iliği transplantasyonu, KCFT: Karaciğer fonksiyon testleri, BFT: Böbrek fonksiyon testleri.

a Tüm hastalarda majör bir komorbidite saptanmıştır.

b Postoperatif 10 hastada konjenital kalp hastalığı mevcuttu.

c Bu bölümdeki yüzdeler önceden antifungal alan 39 hastaya göre ayarlanmıştır. Diğer yüzdeler toplam hasta sayısına $(n=125)$ göre hesaplanmıştır.

${ }^{d}$ Kaybedilen iki olgunun kültüründe Candida türleri üremiştir. Kandidemi $(n=1)$, kandidüri $(n=1)$ mevcuttu.

\begin{tabular}{ll}
\hline Tablo II. Hastaların Bazı Risk Faktörleri $(n=125)$ & \\
\hline Risk faktörü & $\mathbf{n}(\%)$ \\
\hline İmmünsupresif tedavi & $68(\% 54)$ \\
Nötropeni & $61(\% 49)$ \\
Santral venöz kateter & $102(\% 82)$ \\
Nazogastrik sonda & $63(\% 50)$ \\
Endotrakeal entübasyon & $49(\% 39)$ \\
İdrar sondası & $14(\% 11)$ \\
Total parenteral beslenme & $81(\% 65)$ \\
Postoperatif (kardiyovasküler, toraks, gastrointestinal cerrahi) & $18(\% 13)$ \\
\hline
\end{tabular}

anlamlı düzeyde CRP'de azalma $(p=0.001)$, $\operatorname{ALT}^{\prime}$ de azalma $(p=0.009)$, sodyumda hipernatremi olmaksızın artış $(p=0.01)$, hemoglobinde artış $(p=0.005)$ olduğu görülmüştür. Özellikle malignansi olan grupta eritrosit süspansiyonu (ES) desteği ihtiyacının fazla olduğu belirlenmiştir. ES almayan ( $n=87, \% 70$ ) olgularda mikafungin tedavisinin birinci ve dördüncü günü, hemoglobin değerlerinde istatistiksel olarak anlamlı bir farklılık görülmemiştir $(p=0.734)$.

Öncesinde hipokalemi ve nefrotoksisite gelişmiş 33 (\%27) hastada önceki antifungale ya da diğer nedenlere bağlı hipokaleminin; mikafungin sonrası düzeldiği gözlenmiş ( $p=$ $0.011)$, kreatinin değerlerinde değişiklik olmamıştır $(p=0.943)$. Böbrek fonksiyon test- 


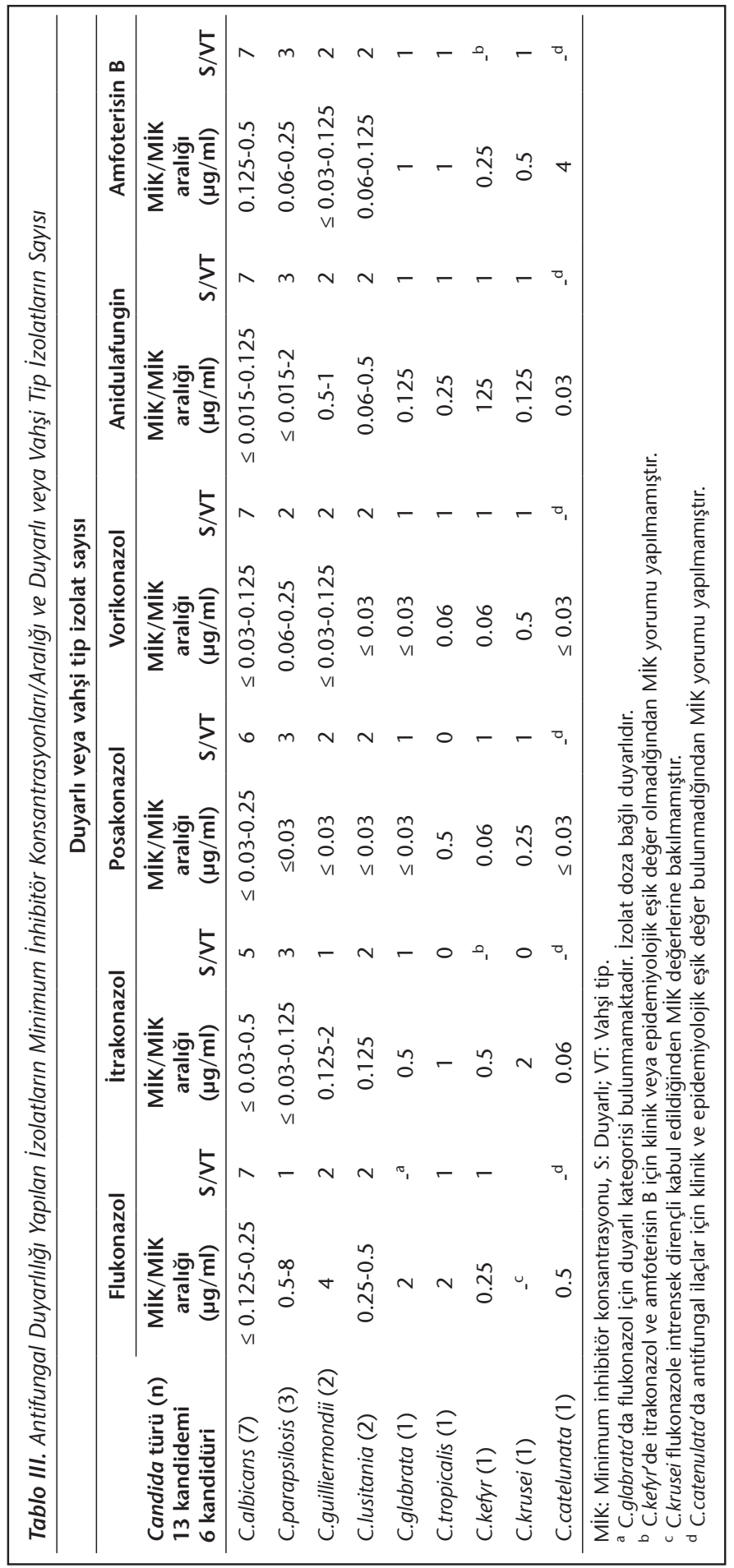




\begin{tabular}{|c|c|c|c|c|}
\hline & & Ort \pm SD & (min-maks), med & p \\
\hline \multirow[t]{2}{*}{ CRP (mg/dl) } & 1. gün & $7 \pm 7.7$ & $(0.1-32), 4.1$ & 0.001 \\
\hline & 4. gün & $5.7 \pm 6.5$ & $(0.1-29), 2.8$ & \\
\hline \multirow[t]{2}{*}{$\mathrm{Hb}(\mathrm{g} / \mathrm{dl})$} & 1. gün & $9.9 \pm 1.9$ & $(6-15), 9.7$ & 0.005 \\
\hline & 4. gün & $10.3 \pm 2$ & $(5.2-16), 10$ & \\
\hline \multirow[t]{2}{*}{ Beyaz küre $\left(/ \mathrm{mm}^{3}\right)$} & 1. gün & $8600 \pm 9068$ & $(10-39.000), 5300$ & 0.29 \\
\hline & 4. gün & $8687 \pm 7880$ & $(20-48.000), 7300$ & \\
\hline \multirow[t]{2}{*}{ Mutlak nötrofil sayısı $\left(/ \mathrm{mm}^{3}\right)$} & 1. gün & $5131 \pm 6500$ & $(0-35.000), 3100$ & 0.448 \\
\hline & 4. gün & $5272 \pm 6400$ & $(0-45.000), 3300$ & \\
\hline \multirow[t]{2}{*}{ Trombosit $\left(/ \mathrm{mm}^{3}\right)$} & 1. gün & $141.207 \pm 149.175$ & (6600-648.000), 79.000 & 0.088 \\
\hline & 4. gün & $147.547 \pm 146.906$ & $(6000-682.000), 97.000$ & \\
\hline \multirow[t]{2}{*}{ Üre (mg/dl) } & 1. gün & $46.6 \pm 53.3$ & (4-449), 28 & 0.862 \\
\hline & 4. gün & $46.6 \pm 55$ & $(3-404), 26$ & \\
\hline \multirow[t]{2}{*}{ Kreatinin (mg/dl) } & 1. gün & $0.66 \pm 0.58$ & $(0.27-5), 0.46$ & 0.16 \\
\hline & 4. gün & $0.67 \pm 0.8$ & $(0.19-7.5), 0.48$ & \\
\hline \multirow[t]{2}{*}{$\operatorname{ALT}(\mathrm{U} / \mathrm{L})$} & 1. gün & $114 \pm 185$ & $(6-1044), 36$ & 0.009 \\
\hline & 4. gün & $97 \pm 168$ & $(4-979), 34$ & \\
\hline \multirow[t]{2}{*}{ AST (U/L) } & 1. gün & $141 \pm 334$ & $(5-2582), 40$ & 0.076 \\
\hline & 4. gün & $103 \pm 255$ & $(4-2091), 36$ & \\
\hline \multirow[t]{2}{*}{ Sodyum (mEq/L) } & 1. gün & $135 \pm 12.3$ & $(10-157), 136$ & 0.01 \\
\hline & 4. gün & $137 \pm 5.6$ & (119-160), 137 & \\
\hline \multirow[t]{2}{*}{ Potasyum (mEq/L) } & 1. gün & $3.7 \pm 0.9$ & $(2-6.4), 3.6$ & 0.052 \\
\hline & 4. gün & $3.9 \pm 0.7$ & $(1.8-6.6), 3.8$ & \\
\hline \multicolumn{5}{|c|}{$\begin{array}{l}\text { * Mikafungin tedavisinin birinci (mikafungin }-2 \text { gün/+1 gün arası) ve dördüncü günü (3-5. günler arası) bakılan } \\
\text { laboratuvar değerleri. }\end{array}$} \\
\hline \multicolumn{5}{|c|}{$\begin{array}{l}\text { Ort: Ortalama, SD: Standart sapma, min: Minimum, maks: Maksimum, med: Ortanca, CRP: C-reaktif protein, } \\
\text { Hb: Hemoglobin, ALT: Alanin aminotransferaz, AST: Aspartat aminotransferaz. }\end{array}$} \\
\hline
\end{tabular}

lerinde bozukluk nedeniyle mikafungin verilen hastalarda hemogram ve biyokimyasal parametrelerde tedavinin birinci ve dördüncü gününde istatistiksel olarak anlamlı fark tespit edilmemiştir.

Hipokalemi nedeniyle antifungal olarak mikafungin tercih edilen 21 (\%17) olguda ise potasyumda artış olduğu gözlenmiştir $(p=0.0001$ ) (Tablo V). Bu hastaların 10'unda daha önce kullanılan antifungale bağlı hipokalemi gelişmiştir.

Öncesinde KCFT'de bozukluk nedeniyle mikafungin verilen hastaların $(n=47, \% 38)$ tedavinin birinci ve dördüncü günü biyokimya parametreleri karşılaştırılmıştır (Tablo VI). ALT ve AST değerlerinde gerileme olduğu görülmüştür (sırasıyla, $p=0.0001$ ve $p=$ $0.0001)$. 
Tablo V. Hipokalemi Görülen Hastaların ( $n=21, \% 17)$ Mikafungin Sonrası Potasyum Değerleri*

\begin{tabular}{llccc}
\hline & & Ort \pm SD & (min-maks), med & p \\
\hline Potasyum $(\mathrm{mEq} / \mathrm{L})$ & 1. gün & $2.7 \pm 0.39$ & $(2-3.5), 2.8$ & $\mathbf{0 . 0 0 0 1}$ \\
& 4. gün & $3.6 \pm 0.45$ & $(2.6-4.4), 3.6$ & \\
\hline
\end{tabular}

* Mikafungin tedavisinin birinci günü (mikafungin -2 gün/+1 gün arası) ve dördüncü günü (3-5. günler arası) bakılan laboratuvar değerleri.

Ort: Ortalama, SD: Standart sapma, min: Minimum, maks: Maksimum, med: Ortanca.

\begin{tabular}{|c|c|c|c|c|}
\hline & & Ort \pm SD & (min-maks), med & $\mathbf{p}$ \\
\hline \multirow[t]{2}{*}{$\operatorname{ALT}(\mathrm{U} / \mathrm{L})$} & 1. gün & $245 \pm 246$ & $(30-1044), 154$ & 0.0001 \\
\hline & 4. gün & $180 \pm 231$ & $(11-979), 89$ & \\
\hline \multirow[t]{2}{*}{ AST (U/L) } & 1. gün & $288 \pm 500$ & $(5-2582), 120$ & 0.0001 \\
\hline & 4. gün & $159 \pm 362$ & $(6-2091), 58$ & \\
\hline \multicolumn{5}{|c|}{$\begin{array}{l}\text { * Mikafungin tedavisinin birinci günü (mikafungin -2 gün/+1 gün arası) ve dördüncü günü (3-5. günler arası) } \\
\text { bakılan laboratuvar değerleri. }\end{array}$} \\
\hline \multicolumn{5}{|c|}{$\begin{array}{l}\text { Ort: Ortalama, SD: Standart sapma, min: Minimum, maks: Maksimum, med: Ortanca, ALT: Alanin aminotransfe- } \\
\text { raz, AST: Aspartat aminotransferaz. }\end{array}$} \\
\hline
\end{tabular}

Öncesinde başka bir antifungal kullanılıp tedavisi mikafungin ile değiştirilen yenidoğan dahil olgularda ( $n=39 / 125, \% 31)$ mikafunginin birinci ve dördüncü günü bazı kan sayımı ve biyokimya değerleri karşılaştıııldığında, tedavi sonrası sadece CRP'de azalma anlamlı bulunmuştur $(p=0.025)$. KCFT yüksekliği nedeniyle mikafungin tercih edilen, öncesinde antifungal kullanılan olgularda ( $n=14 / 39, \% 36)$ ALT, AST değerlerinde azalma olmakla birlikte, bu azalma istatistiksel olarak anlamlı bulunmamıştır. Hipokalemi yan etkisi nedeniyle antifungal tedavi değişikliğine gidilen olgularda $(n=10 / 39, \% 26)$ potasyum değerlerinde hiperkalemi olmaksızın anlamlı artış olduğu görülmüştür $(p=0.003)$; kreatinin ve sodyumda ( $n=5 / 39, \% 13$ olguda) değişiklik olmamıştır.

Yenidoğan 33 (\%26) olgu incelendiğinde mikafungin kullanımının birinci ve dördüncü günü tam kan sayımı ve biyokimyasal parametreler karşılaşııııldığında hipernatremi olmaksızın sodyum artışını $(p=0.003)$ ve kreatininde azalmanın $(p=0.014)$ istatistiksel olarak anlamlı olduğu görülmüştür. KCFT yüksekliği nedeniyle mikafungin tedavisi verilen yenidoğanlarda ( $n=11, \% 33)$ AST değerinde düşme $(p=0.045)$, hipokalemi nedeniyle mikafungin tedavisi verilenlerde $(n=5, \% 15)$ kan üre seviyesinde azalma $(p=0.023)$, potasyumda artış olduğu $(p=0.046)$ gözlenmiştir. Öncesinde başka bir antifungal kullanıp ( $n=12, \% 36)$ KCFT yüksekliği nedeniyle mikafungin tedavisi verilen 4 (\%33) yenidoğanda üre, ALT, AST değerlerinde değişiklik gözlenmemiştir. Öncesinde başka bir antifungal kullanıp hipokalemi nedeniyle mikafungin verilen 5 (\%42) yenidoğanda ise potasyum ve sodyumda artış istatistiksel olarak anlamlı bulunmuştur $(p=0.04, p=0.017)$. 
Nötropenik olgular nötropeni derecesine göre $\left(<100,100-500,500-1500 / \mathrm{mm}^{3}\right)$ sInıflandırıldığında, mikafungin tedavisiyle birinci ve dördüncü gün hemogram ve biyokimyasal parametrelerinin yüzde değişim farkı arasında beyaz küre ve nötrofil değerleri haricinde istatistiksel olarak anlamlı fark görülmemiştir.

Olgular mikafungin tedavisinin yan etkileri açısından incelendiğinde, eş zamanlı kemoterapi de almakta olan iki olguda mikafungin infüzyonu sonrası bulantı ve kusma geliştiği gözlenmiştir. Hiçbir hastada tedavi değişimi gerektirecek önemli bir yan etki gözlenmemiştir.

Olguların \%15 ( $n=19)^{\prime}$ i mikafungin tedavisinin ilk 30 günü içerisinde kaybedilmiş olup yalnız birinde kandidemi tespit edilmiştir.

\section{TARTIŞMA}

İnvaziv fungal enfeksiyonlar morbidite ve mortaliteyi önemli ölçüde etkileyen, hastane yatışını uzatan ve maliyeti artıran önemli bir sorundur. İnvaziv kandidiyaziste mortalite \%20-30 arasında değişmektedir. En büyük risk faktörleri; geniş spektrumlu antibiyotik kullanımı, parenteral beslenme, intravasküler kateterizasyon varlığı, immünsupresyon, düşük doğum ağırlığı, fungal kolonizasyon, nekrotizan enterokolit, mekanik ventilasyon ve geçirilmiş cerrahi girişimlerdir ${ }^{15}$. Çalışmamızda olguların $\% 94^{\prime}$ ünün geniş spektrumlu antibiyotik aldığı, \%82'sinde santral venöz kateterinin olduğu, \%65'inin parenteral beslenmekte olduğu gözlenmiş̧tir.

Ekinokandinler, invaziv fungal enfeksiyon şüphelenilen ve kanıtlanan erişkinlerde kullanılabilirken, çocuk hastalar ile ilgili veriler sınırıdır. FDA dört ay ve üzeri, EMA ise yenidoğan dahil tüm yaş gruplarında mikafungin kullanımı için onam vermiştir ${ }^{3,4}$. Ülkemizde 18 Haziran 2016 tarihinden itibaren Sağlık Uygulamalar Tebliği (SUT) geri ödeme kapsamındadır. Öncesinde "klasik amfoterisin B'ye alerjik reaksiyon gösterdiğinin uzman hekim raporu ile belgelenmesi ya da hastanın karaciğer veya böbrek fonksiyon testlerinin laboratuvar verileri ile bozuk olduğunun belgelenmesi halinde mikafungin kullanılabilir" şeklinde mikafungin kullanım ilkeleri belirtilmişken, 21 Mart 2018 tarihli SUT değişikliği doğrultusunda bu şartlar kaldırıımıştır ${ }^{16}$. Olgularımızın \%48 $(n=60)^{\prime}$ ine SUT değişimi öncesi mikafungin başlandığı saptanmıştır.

Mikafunginin yenidoğanda kullanım bilgileri sınırlı olup, beyin omurilik sıvısı (BOS)'na geçiş için yüksek dozlara gereksinim duyulması ilaç hakkındaki önemli belirsizlikler arasında yer almaktadır. Mikafungin kliniklerimizde SUT ödeme kapsamında, 2-4 mg/kg/ gün, tek doz, maksimum 200 mg/gün dozunda kullanılmıştır. Yenidoğanlarda ise 10 mg/ $\mathrm{kg} / \mathrm{gün}$ dozunda kullanılmış ve bu dozlarda tolere edilebilmiştir. EMA'da mikafunginin yüksek dozlarda BOS'a geçebilmesi nedeniyle $10 \mathrm{mg} / \mathrm{kg} / \mathrm{gün}$ verilebileceğini belirtmiş$\mathrm{tir}^{4}$. Yenidoğanda $15 \mathrm{mg} / \mathrm{kg} / \mathrm{gün}$ dozunda kullanılıp yan etki gözlenmeyen çalışmalar da mevcuttur $^{17}$.

Kuse ve arkadaşlarının yayınladığı bir çalışmada6; invaziv kandidiyazis nedeniyle mikafungin tedavisi alan 202 erişkin olgu ile lipozomal amfoterisin B tedavisi alan 190 erişkin 
olgu karşılaştırılmıştır. Mikafungin ve lipozomal amfoterisin B'nin tedavi başarıları benzer görülmüş, tedavi sırasında görülen yan etkilerin mikafungin grubunda daha az olduğu gözlenmiştir. Çocuklarda invaziv kandidiyazis olgularında yapılmış benzer bir çalışmada da, 48 olguya mikafungin, 50 olguya lipozomal amfoterisin B verilmiş, tedavi etkinliği benzer bulunmuş olup; hipokalemi, ateş, infüzyon ilişkili reaksiyon gibi yan etkilerin mikafungin grubunda daha düşük olduğu saptanmıştır ${ }^{18}$. Mikafungin ve kaspofunginin invaziv kandidiyazisde karşılaştırıldığı erişkin hasta grubunda yapılan çalışmada tedavi etkinliği ve yan etki kıyaslamasında anlamlı fark olmadığı gözlenmiştir ${ }^{19}$.

Çalışmamızda mikafungine bağlı ateş, infüzyon ilişkili reaksiyon, ishal gibi yan etkiler gözlenmemiş olup iki olguda infüzyon sonrası bulantı ve kusma gözlenmiştir. Ancak, eş zamanlı kemoterapi verilen bu hastalarda mevcut yan etkinin mikafungine bağlı olmadığı düşünülmüştür. Nitekim, mikafungine devam edilmesine rağmen, sonraki dozlarda bu yan etkilerin oluşmadığı gözlenmiştir. IME olan olguların hiçbirinde Candida'ya bağlı endoftalmit, endokardit, karaciğer/dalak tutulumu gibi sistemik kandidiyazis bulgularının olmadığı izlenmiştir.

Çalışmamızda olguların \%94'ünde geniş spektrumlu antibiyotik kullanımı olduğu belirlenmiş, tedaviye mikafungin eklenmesi ve ardından CRP'de azalma gözlenmesi nedeniyle, bu azalmanın büyük ölçüde mikafungin ile ilişkili olduğu düşünülmüştür. Diğer laboratuvar parametrelerini düzeltmek amacıyla çeşitli medikal tedavilerin (elektrolit replasmanı, hepatotoksisite/nefrotoksisiteye neden olan tedavinin kesilmesi vb.) de verilmesinden dolayı, veriler doğrultusunda mikafunginin bu parametreleri olumsuz etkileyecek yan etkilere neden olmadığı söylenebilir.

Çalışmamızda kan ve idrar kültürlerinde üreyen toplam 19 izolata antifungal duyarlılık çalışılmıştır. İ vitro antifungal duyarlılık testlerinde anidulafungin ya da mikafungin, ekinokandin duyarlılığının tespitinde eşdeğer olarak kullanılabildiğinden, bu çalışmada da laboratuvarımız rutininde bulunan anidulafungin sonuçları mikafungin etkinliği açısından yeterli kabul edilmiştir ${ }^{20}$. Klinik sınır ve epidemiyolojik eşik değerleri bulunmadığı için değerlendirilemeyen Candida catenulata hariç diğer bütün izolatlar anidulafungine (mikafungin dahil ekinokandinlere) duyarlı bulunmuştur. Kandidemi olan olguların 5 (\%38)'i yenidoğan olup, 3 (\%23)'ünde C.albicans dışı türler üremiştir. Antifungal duyarlılık çalışılan Candida türlerinin hepsinde ekinokandin duyarlılığı gözlenmiş olup, tüm üremelerde ortanca dört günde kontrol kültürler üremesiz gelerek mikafungin ile etkili tedavi yapılmıştır. Antifungal ilaç seçiminin epidemiyoloji üzerindeki etkisini izlemek için Candida türlerinin antifungal duyarlılık paternlerini takip etmek ve düzenli sürveyans çalışmaları yapmak gerekmektedir.

S.cerevisiae fungemisi olan olgumuz, 3.5 yaşında leptomeningeal karsinomatozis tanısı olan, uzun süredir deksametazon tedavisi kullanmakta olup çocuk yoğun bakım ünitesinde entübe olarak izlenmiştir. Total parenteral beslenme alan olgunun ateş ve akut faz reaktanlarında yükselme olması üzerine nozokomiyal septisemi tanısıla alınan periferik dört kan kültüründe S.cerevisiae ürediği saptanmıştır. Mikafungin tedavisi ile tedavinin 
dördüncü günü akut faz reaktanları ve kan kültürleri negatifleşmiştir. Bu olguda predispozan olarak uzun süre kortikosteroid kullanımı nedeniyle immünsupresyonun olduğu ve ishal nedeniyle S.cerevisiae içeren probiyotik verildiği saptanmıştır. Ülkemizde ve yurt dışında ekinokandin tedavisi ile iyileşen benzer olgular bildirilmiştir ${ }^{21,22}$.

Bu çalışmada yer alan yenidoğan bebekler incelendiğinde, KCFT yüksekliği nedeniyle mikafungin tedavisi verilen yenidoğanlarda ALT, AST değerlerinde azalma görülmüştür. AST'deki azalma istatistiksel olarak anlamlı bulunmuştur. Tedavide daha önce kullanılan antifungale bağlı olarak gözlenen hipokalemi durumunda sodyum ve potasyum değerlerinde mikafungin tedavisi sonrasında istatistiksel olarak anlamlı artış gözlenmiştir. Tübülopatisi olan tüm yenidoğanlarda ise, kreatininde azalma ve sodyumda artış istatistiksel olarak anlamlı olup, veri sayısı yetersiz olmakla birlikte, tübülopati durumunda yenidoğanda mikafungin tedavisinin öncelikli tercih edilebileceği sonucuna varılmıştır. Benzer bir çalışmada da mikafungin kullanımının yenidoğanda güvenli ve etkin kullanılabileceği gözlenmiştir ${ }^{23}$.

Çalışmamızda olguların \%15 ( $n=19)^{\prime} i$ mikafungin tedavisinin ilk 30 günü içerisinde kaybedilmiş olup bunlardan sadece iki olgunun kültürlerinde mantar üremesi olduğu saptanmıştır. Primer hemofagositik lenfohistiyositoz tanısı olan ve immünsupresan tedavi ile total parenteral beslenme alan bir olguda kan kültüründe C.albicans üremiştir. Diğer olgu ise, konjenital kalp hastalığı nedeniyle yeni opere olmuş bir Down sendromlu olup idrar kültüründe Candida keyfr üremiştir. Predispozan faktör olarak bu olgunun entübe olduğu, idrar sondası ve santral venöz kateteri bulunduğu ve geniş spektrumlu antibiyotik ile total parenteral beslenme aldığı izlenmiştir. Her iki olguda da 10 günün üzerinde genişs spektrumlu antibiyotik kullanımı olduğu gözlenmiştir.

Ekinokandinlerin kullanılma sıklığı hastanede yatan çocuklarda zamanla önemli ölçüde artmıştır. Çocuklarda hastanede yatış süresinin uzaması, uzun süre geniş spektrumlu antibiyotik kullanımı, geçirilmiş operasyon, kateterizasyon/parenteral beslenme uygulanması gibi risk faktörlerinin artışı invaziv kandidiyazis gelişimini artırmakta ve etkin tedavi için yan etki potansiyeli düşük, güçlü antifungal ilaçlara gereksinimi artırmaktadır. Mikafunginin yan etki potansiyelinin düşük ve kaspofungine göre yenidoğan ve üç ayın altındaki bebekler de dahi endikasyon doğrultusunda kullanılabilir olması, pediatride yenidoğan dahil tüm çocukluk yaş grubunda önerilebilecek sistemik bir antifungal olabileceğini düşündürmektedir.

SUT ödeme kapsamına alındıktan sonra, ülkemizde pediatrik hastalarda ilk mikafungin kullanım deneyimi kliniğimizde olmuştur. Mikafungin etkinlik ve yan etkisi araştırılan, deneyimlerimizi paylaştığımız bu çalışmamız, literatür taramamız kapsamında, Türkiye'de gerçekleştirilen en geniş yaş grubu ve hasta sayısını içeren çalışmadır.

Sonuç olarak bu çalışma, iME tedavisinde mikafunginin, böbrek ve karaciğer fonksiyon testleri bozuk olan hastalar da dahil olmak üzere yenidoğandan itibaren tüm çocukluk yaş grubunda, güvenli ve etkili bir seçenek olabileceğini göstermektedir. 


\section{ÇIKAR ÇATIŞMASI}

\section{Yazarlar bu makale ile ilgili herhangi bir çıkar çatışması bildirmemişlerdir.}

\section{KAYNAKLAR}

1. Wagener J, Loiko V. Recent insights into the paradoxical effect of echinocandins. J Fungi (Basel) 2017;4(1):5.

2. Hope WW, Castagnola E, Groll AH, Roilides E, Akova M, Arendrup MC, et al. ESCMID* guideline for the diagnosis and management of Candida diseases 2012: prevention and management of invasive infections in neonates and children caused by Candida spp. Clin Microbiol Infect 2012;18(7):38-52.

3. Food and Drug Agency, Mycamine Drug Information, 23/03/2019 https://www.fda.gov/advisory-committees/pediatric-advisory-committee/mycamine-micafungin-sodium-briefing-materials. Erişim tarihi: 22/05/2019.

4. Mycamine: EPAR-Product Information, 01/03/2018, https://www.ema.europa.eu/en/documents/productinformation/mycamine-epar-product-information_en.pdf. Erişim tarihi 22/05/2019.

5. Pappas PG, Kauffman CA, Andes DR, Cornelius JC, Kieren AM, Ostrosky-Zeichner L, et al. Clinical practice guideline for the management of candidiasis: 2016 Update by the Infectious Diseases Society of America. Clin Infect Dis 2016;62(4):1-50.

6. Kuse ER, Chetchotisakd P, da Cunha CA, Ruhnke M, Barrios C, Digumarti R, et al. Micafungin versus liposomal amphotericin B for Candidaemia and invasive candidosis: a phase III randomised double-blind trial. The Lancet 2007;369(9572):1519-27.

7. Cuenca-Estrella M, Verweij PE, Arendrup MC, Arikan-Akdagli S, Bille J, Donnelly JP, et al. ESCMID* guideline for the diagnosis and management of Candida diseases 2012: diagnostic procedures. Clin Microbiol Infect 2012;18(7):9-18.

8. Clinical and Laboratory Standard Institute. Reference method for broth dilution antifungal susceptibility testing of yeasts: Approved standard-third edition CLSI document M27-A3, 2008. CLSI, Wayne, PA.

9. Clinical and Laboratory Standard Institute. Reference method for broth dilution antifungal susceptibility testing of yeasts: Approved standard-third edition. CLSI document M27-S3, 2008. CLSI, Wayne, PA.

10. Pfaller MA, Diekema DJ. Progress in antifungal susceptibility testing of Candida spp. by use of Clinical and Laboratory Standards Institute broth microdilution methods, 2010 to 2012. J Clin Microbiol 2012;50(9):284656.

11. Ahsan S, Noether J. Neutropenia, pp: 332-333. In: Arcara KM, Tschudy MM (eds), The Harriet Lane Handbook. 2012, 19th ed. The Johns Hopkins Hospital, Elsevier, Mosby.

12. De Pauw B, Walsh TJ, Donnelly JP, Stevens AD, Edwards JE, Calandra T, et al. Revised definitions of invasive fungal disease from the European Organization for Research and Treatment of Cancer/Invasive Fungal Infections Cooperative Group and the National Institute of Allergy and Infectious Diseases Mycoses Study Group (EORTC/MSG) Consensus Group. Clin Infect Dis 2008;46(12):1813-21.

13. Freifeld AG, Bow EJ, Sepkowitz KA, Boeckh MJ, Ito JI, Mullen CA, et al. Clinical practice guideline for the use of antimicrobial agents in neutropenic patients with cancer: 2010 Update by the Infectious Diseases Society of America. Clin Infect Dis 2011;52(4):427-31.

14. Katragkou A, Roilides E. Best practice in treating infants and children with proven, probable or suspected invasive fungal infections. Curr Opin Infect Dis 2011;24(3):225-9.

15. Tsekoura M, loannidou M, Pana ZD, Anna-Bettina H, Charalampos A, losifidis E, et al. Efficacy and safety of echinocandins for the treatment of invasive candidiasis in children: a meta-analysis. Pediatr Infect Dis J 2019;38(1):42-8.

16. Sosyal Güvenlik Kurumu Sağlik Uygulama Tebliğinde Değişiklik Yapilmasina Dair Tebliğ 21/03/2018, Sayı:30367, http://www.resmigazete.gov.tr/eskiler/2018/03/20180321-8.htm. Erişim tarihi 22/05/2019.

17. Rivera-Chaparro ND, Ericson J, Wu H, Simith PB, Clark R, Benjamin DK, et al. Safety, effectiveness, and exposure-response of micafungin in infants: Application of an established pharmacokinetics model to electronic health records. Pediatr Infect Dis J 2019;38(2):26-8. 
18. Queiroz-Telles F, Berezin E, Leverger G, Freire A, van der Vyver A, Chotpitayasunondh T, et al. Micafungin versus liposomal amphotericin B for pediatric patients with invasive candidiasis: substudy of a randomized double-blind trial. Pediatr Infect Dis J 2008;27(9):820-6.

19. Pappas PG, Rotstein CM, Betts RF, Nucci M, Talwar D, De Waele J], et al. Micafungin versus caspofungin for treatment of candidemia and other forms of invasive candidiasis. Clin Infect Dis 2007;45(7):883-93.

20. Posteraro B, Torelli R, Carolis E, Posteraro P, Sanguinetti M. Antifungal susceptibility testing: current role from the clinical laboratory perspective. Mediterr J Hematol Infect Dis 2014;6(1):2014030.

21. Fadhel M, Patel S, Liu E, Levitt M, Asif A. Saccharomyces cerevisiae fungemia in a critically ill patient with acute cholangitis and long term probiotic use. Med Mycol Case Rep 2019;23:23-5.

22. Eren Z, Gurol Y, Sonmezoglu M, Eren HS, Celik G, Kantarci G. Saccharomyces cerevisiae fungemia in an elderly patient following probiotic treatment. Mikrobiyol Bul 2014;48(2):351-5.

23. Çağrı ÇS, Solmaz Ç, Hilal Ö, Köksal N, Dorum BA, Yeşil E, et al. Yenidoğanlarda mikafungin kullanımı sonuçları. Mikrobiyol Bul 2019;53(1):70-80. 